\title{
Inhibition of Colonic Tumor Growth by the Selective SGK Inhibitor EMD638683
}

\author{
Syeda T. Towhid ${ }^{\text {Gui-Lai Liu }}{ }^{a}$ Teresa F. Ackermann ${ }^{a}$ Norbert Beier ${ }^{b}$ \\ Wolfgang Scholz ${ }^{b}$ Thomas Fuch $\beta^{b}$ Mahmoud Toulany ${ }^{c}$ Hans-Peter Rodemann ${ }^{c}$ \\ Florian Langa
}

aDepartment of Physiology, University of Tübingen, Tübingen; ${ }^{b}$ Merck KGaA, Darmstadt; 'Division of Radiobiology \& Molecular Environmental Research, Department of Radiation Oncology,

University of Tüebingen, Tübingen, Germany

\section{Key Words}

Colon carcinoma - Serum and glucocorticoid inducible kinase - Cell volume - Apoptosis • Mitochondrial potential $\cdot$ Caspase $3 \cdot$ Radiation

\begin{abstract}
Background: The serum and glucocorticoid inducible kinase SGK1, which was originally cloned from mammary tumor cells, is highly expressed in some but not all tumors. SGK1 confers survival to several tumor cells. Along those lines, the number of colonic tumors following chemical carcinogenesis was decreased in SGK1 knockout mice. Recently, a highly selective SGK inhibitor (EMD638683) has been developed. The present study explored whether EMD638683 affects survival of colon carcinoma cells in vitro and impacts on development of colonic tumors in vivo. Methods: Colon carcinoma (Caco-2) cells were exposed to EMD638683 with or without exposure to radiation ( 3 Gray) and cell volume was estimated from forward scatter, phosphatidylserine exposure from annexin $\mathrm{V}$ binding, mitochondrial potential from JC-9 fluorescence, caspase 3 activity from CaspGlow Fluorescein staining, DNA degradation from propidium iodide staining as well as late apoptosis from annexin-V FITC and propidium iodide double staining. In vivo tumor growth was determined in wild type mice subjected to chemical carcinogenesis (intraperitoneal injection of $20 \mathrm{mg} / \mathrm{kg}$ 1,2-dimethylhydrazine followed by three cycles of $30 \mathrm{~g} / \mathrm{L}$ synthetic dextran sulfate sodium in drinking water for 7 days). Results: EMD638683 treatment significantly augmented the radiation-induced decrease of forward scatter, increase of phosphatidylserine exposure, decrease of mitochondrial potential, increase of caspase 3 activity, increase of DNA fragmentation and increase of late apoptosis. The in vivo development of tumors following chemical carcinogenesis was significantly blunted by treatment with EMD638683. Conclusions: EMD638683 promotes radiation-induced suicidal death of colon tumor cells in vitro and decreases the number of colonic tumors following chemical carcinogenesis in vivo.
\end{abstract}

Copyright (C) 2013 S. Karger AG, Basel 


\section{Introduction}

SGK1 was originally cloned as a gene transcriptionaly up-regulated by serum and glucocorticoids in rat mammary tumor cells [1]. Human SGK1 was discovered as a cell volume-regulated gene, up-regulated by cell shrinkage [2]. SGK1 transcription is stimulated by several additional hormones and mediators including mineralocorticoids, gonadotropins, calcitriol, transforming growth factor $\beta$ (TGF- $\beta$ ), interleukin 4 , fibroblast growth factor and platelet-derived growth factor [3]. SGK1 is expressed in all tissues tested thus far [2]. SGK1 is activated by growth factors, an effect involving phosphatidylinositide (PI) 3-kinase and phosphoinositide-dependent kinase 1 (PDK1) signaling [3].

SGK1 is highly expressed in several tumor cells [4], such as colon cancer [4], myeloma [5], medulloblastoma [6], prostate cancer [7], ovarian tumors [8] and non-small cell lung cancer [9]. On the other hand, down-regulation of SGK1 in some tumors has been reported, including adenomatous polyposis coli (APC) $[3,4,10]$. SGK1 expression is apparently not required for the survival of those tumor cells. Nevertheless, genetic knockout of SGK1 significantly decreased the number of spontaneous tumors in APC-deficient mice [11] and of colonic tumors following chemical carcinogenesis [12].

Several observations point to a role of SGK1 in cell survival [13-15]. SGK1 has been shown to inhibit apoptosis of Madin-Darby canine kidney (MDCK) [14] and breast cancer [15] cells and to confer interleukin (IL)-6-dependent survival of cholangiocarcinoma cells [16]. Transformation of intestinal epithelial cells by oncogenic $\beta$-catenin was followed by increased SGK1 expression $[17,18]$.

The selective SGK1 inhibitor GSK650394 proved to be effective in vitro against prostate cancer cells [19] and LY294002 against breast cancer [20]. The IC50 of GSK 650394 is 0.6 $\mu \mathrm{M}$ [19]. More recently, the highly selective SGK inhibitor EMD638683 has been developed, which is effective in vivo [21]. In Hela cells, EMD638683 was tested with regard to the SGK1dependent phosphorylation of NDRG1 (N-Myc downstream-regulated gene 1) [21]. The IC50 value of EMD638683 for this (in vitro) activity is $3 \mu \mathrm{M}$. While EMD638683 may inhibit the other two SGK isoforms with similar potency [21], in a biochemical assay (measuring inhibition of enzyme activity), more than one order of magnitude higher concentrations are required to inhibit mitogen- and stress-activated protein kinase 1 MSK1 and protein kinase A [21]. More than two orders of magnitude higher concentrations were required for any of the other kinases tested [21]. EMD638683 is readily soluble in water and is the first SGK inhibitor shown to be effective in vivo [21]. The substance has previously been shown to reverse the hypertension following hyper-insulinemia and salt excess [21]. The present study explored whether EMD638683 could foster suicidal death of cultured colon carcinoma cells in vitro and counteract colonic tumor growth in vivo. To this end, chemical carcinogenesis has been induced by 1,2-dimethylhydrazine/dextran sulfate sodium treatment in mice without or with EMD638683 treatment.

\section{Materials and Methods}

Experiments in CaCo-2 cells

Colon carcinoma (CaCo-2) cells were grown in complete DMEM medium containing 10\% fetal calf serum, $1 \%$ sodium pyruvate, $1 \%$ penicillin-streptomycin and $1 \%$ non-essential amino acids (all from PAA, Austria) under standard culture conditions $\left(37^{\circ} \mathrm{C}, 5 \% \mathrm{CO}_{2}\right) \cdot 10^{5}$ cells were seeded in 6 well plates and cultured with fresh culture medium for $24 \mathrm{~h}$, after which EMD638683 (50 $\mu \mathrm{M})$ was applied for 24 hours. For comparison, the cells were treated with the solvent ( $0.2 \mu \mathrm{l}$ DMSO) and one solvent control was analysed with each set of experiments. The cells were subsequently exposed to 3.18 min radiation (3 Gray). After further incubation for $72 \mathrm{~h}$ in the presence or absence of EMD638683 (50 $\mu \mathrm{M})$ the cells were analyzed utilizing flow cytometry (BD FACS Calibur, BD Biosciences, USA).

For FACS analysis the cultured cells were detached from the 6-well plate by treatment with $1 \mathrm{x}$ trypsin-EDTA (PAA, Austria) for 15 minutes. The cells were washed with DMEM media with 10\% FBS 
by centrifugation at 1600 RPM for 3 minutes. $10^{5}$ cells were suspended in $200 \mu$ PBS. Cell volume was estimated from forward scatter in FACS analysis.

Depolarization of the outer membrane of mitochondria was measured by incubating $10^{5}$ cells in $10 \mathrm{ng} /$ $\mathrm{ml}$ concentration of JC9 (Invitrogen, USA) in the dark for 10 minutes at $37^{\circ} \mathrm{C}$. The cells were washed once in PBS at 1600 RPM for 3 minutes and measured immediately by flow cytometry. JC-9 is a cationic dye which accumulates selectively in the mitochondria and undergoes a potential-dependent shift of fluorescence emission from $525 \mathrm{~nm}$ (FL1) to $590 \mathrm{~nm}$ (FL2). Therefore, cells with hyperpolarized mitochondria are in the upper right quadrant of an FL1 vs FL2 dot plot whereas cells with depolarized mitochondria are in the lower quadrants (Product Information for JC-9, Invitrogen, USA).

Active caspase- 3 was measured by CaspGlow Fluorescein Active Caspase-3 Staining kit from BioVision (CA, USA) adhering to the manufaturer's instruction. Briefly, $10^{5}$ cells were suspended in $100 \mu$ l complete DMEM, stained for 1 hour with $0.1 \mu \mathrm{l}$ active caspase-3 FITC antibody under cell culture conditions. The cells were then washed once in $200 \mu \mathrm{l}$ wash buffer supplied in the kit and resuspended in $200 \mu \mathrm{l}$ wash buffer for immediate FACS analysis.

To determine apoptosis, $10^{5}$ cells $/ 100 \mu \mathrm{l}$ in complete DMEM were incubated in $70 \%$ ethanol (molecular grade, Sigma) on ice for 30 minutes, centrifuged at $1600 \mathrm{RPM}$ for 3 minutes at $4^{\circ} \mathrm{C}$, added to $200 \mu$ l of hypotonic buffer $\left(0.1 \%\right.$ sodium citrate, $0.1 \%$ triton X-100, $2 \mathrm{mM} \mathrm{CaCl}_{2}, 20 \mathrm{U} / \mathrm{ml}$ RNAse A in deionized water) together with $24 \mu \mathrm{l} / \mathrm{ml}$ Annexin V FITC (Mabtag, Germany) and $50 \mu \mathrm{g} / \mathrm{ml}$ propidium iodide (Mabtag, Germany) and incubated on ice in the dark for 60 minutes. The cells were washed once at 1600 RPM for 3 minutes, resuspended in PBS-1\% BSA and measured immediately yielding a FL-1 vs FL-2 dot plot in FACS.

\section{Experiments in mice}

Experiments were carried out on wild type mice as previously described [12]. The animals were housed under controlled environmental conditions $\left(22-24^{\circ} \mathrm{C}, 50-70 \%\right.$ humidity and a $12 \mathrm{~h} \mathrm{light/dark} \mathrm{cycle).}$ Throughout the study mice had free access to tap water and pelleted food. The animals received either placebo food or food containing EMD638683 (4460 ppm in the chow, which resulted in a dose of approx. $600 \mathrm{mg}$ / $\mathrm{kg} /$ day). All animal experiments were conducted according to the guidelines of the American Physiological Society and the German law for the care and welfare of animals and were approved by local authorities (Regierungspräsidium Tübingen). Colonic tumors were generated as described previously [22]. At the age of 8 weeks the animals were treated intra-peritoneally with $20 \mathrm{mg} / \mathrm{kg}$ 1,2-dimethylhydrazine (DMH; SigmaAldrich Corp. St.Louis MO. USA, preparation in $0.9 \%$ saline) and subsequently by three cycles of alternating administration of drinking water containing $30 \mathrm{~g} / \mathrm{L}$ synthetic dextran sulfate sodium (DSS; molecular mass $5000 \mathrm{~g} / \mathrm{mol}$; Wako Pure Chemical Industries, Led. Japan) for 7 days followed by drinking water lacking DSS for subsequent 14 days. The treatment leads to appearance of tumors specifically in colonic tissue with predominant localization in the distal part of the colon $[22,23]$. All mice were anesthetized with ether and sacrificed at the age of 20 weeks. After death, the entire colorectum from the colocecal junction to the anal verge was examined. Fresh specimens were placed in liquid nitrogen and subsequently stored at $-80^{\circ} \mathrm{C}$ for further analysis. The colon length was measured, as inflammation and tumor growth results in shortening of the colon $[22,24]$. Then, the colon was opened longitudinally, washed with PBS, and divided into three portions (proximal, middle and distal). After macroscopic inspection the colon was fixed in a formaldehyde buffer solution ( $\mathrm{pH}$ 7.4).

\section{Statistical analysis}

Data are provided as means \pm SD, $n$ represents the number of independent experiments. Data were tested for significance using ANOVA (one-way ANOVA) and paired student's t-test. Differences were considered statistically significant, if $p$-values were $<0.05$.

\section{Results}

In a first series of experiments the effect of the selective SGK inhibitor EMD638683 was tested in vitro. To this end, human colon carcinoma (CaCo-2) cells were exposed for 24 hours to $50 \mu \mathrm{M}$ EMD638683 prior to radiation or, for comparison, to $0.2 \mu \mathrm{l}$ solvent DMSO. The cells were subsequently exposed for 3.18 minutes to radiation ( 3 Gray). As illustrated in Fig. 1, 


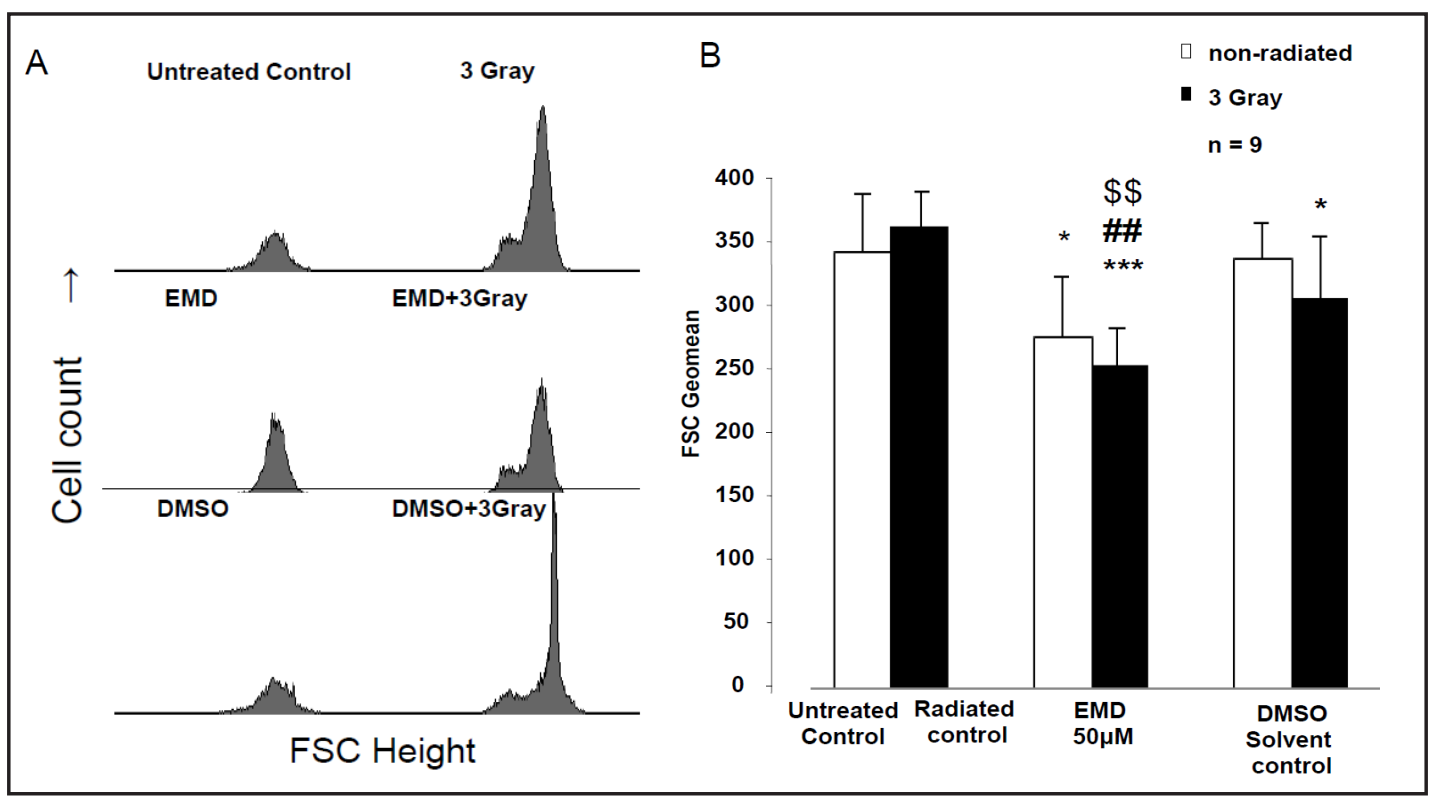

Fig. 1. Effect of radiation and/or EMD638683 on CaCo-2 cell forward scatter. A. Original histograms of forward scatter of colon carcinoma (Caco-2) cells without (left panels) and with (right panels) a 3.18 minute exposure to radiation ( 3 Gray) $72 \mathrm{~h}$ prior to measurements without and with a $24 \mathrm{~h}$ exposure to 50 $\mu \mathrm{M}$ EMD638683. B. Arithmetic means \pm SD $(n=9)$ of the average forward scatter of Caco-2 cells following a $24 \mathrm{~h}$ exposure in the absence (control) or presence of $50 \mu \mathrm{M}$ EMD638683 (EMD) or $0.2 \mu$ l solvent Dimethyl sulfoxide (DMSO) without (white bars) and with (black bars) an additional 3.18 min exposure to radiation (3 Gray). Forward scatter measured in FACS is indicative of cell volume.* $(p<0.05)$ and ${ }^{* * *}(p<0.001)$ indicates significant difference to respective value of untreated control and \#\# $(p<0.05)$ indicates significant difference to respective value without radiation ( $\mathrm{t}$-test) and $\$ \$(\mathrm{p}<0.05)$ indicates significant difference to DMSO.

EMD638683 treatment alone did not significantly modify the forward scatter of CaCo-2 cells, but significantly augmented the cell shrinkage following radiation.

As shown in Fig. 2, EMD638683 treatment alone tended to enhance the percentage of CaCo-2 cells with depolarized mitochondria. Similarly, radiation alone tended to enhance the percentage of CaCo-2 cells with depolarized mitochondria. The percentage of CaCo-2 cells with depolarized mitochondria was significantly increased by radiation of EMD638683-treated CaCo-2 cells. The same observations were made on caspase activity (Fig. 3). EMD638683 treatment alone tended to enhance caspase activity. Similarly, radiation alone tended to enhance caspase activity. The caspase activity was significantly increased by radiation of EMD638683-treated CaCo-2 cells.

To identify cells undergoing apoptosis, cell membrane scrambling with exposure of phosphatidylserine (PS) on the membrane surface was elucidated by determination of annexin- $V$ binding and the degradation of nuclear DNA by propidium iodide staining (Fig. 4A). As illustrated in Fig. 4B, treatment with EMD638683 tended to enhance the percentage of annexin $\mathrm{V}$ binding CaCo-2 cells. Radiation significantly increased the percentage of annexin $\mathrm{V}$ binding CaCo-2 cells both, in the presence and absence of EMD638683. The percentage annexin $\mathrm{V}$ binding radiated CaCo-2 cells was, however, significantly higher in the presence than the absence of EMD638683. Thus, EMD638683 treatment significantly augmented the annexin $\mathrm{V}$ binding following radiation.

The same observations were made on late apoptosis. In both, control and EMD638683-treated CaCo- 2 cells, radiation significantly increased the percentage of CaCo-2 cells undergoing late apoptosis (Fig. 4C). EMD638683 treatment alone tended to enhance the percentage of apoptotic CaCo-2 cells. Following radiation the percentage of apoptotic 


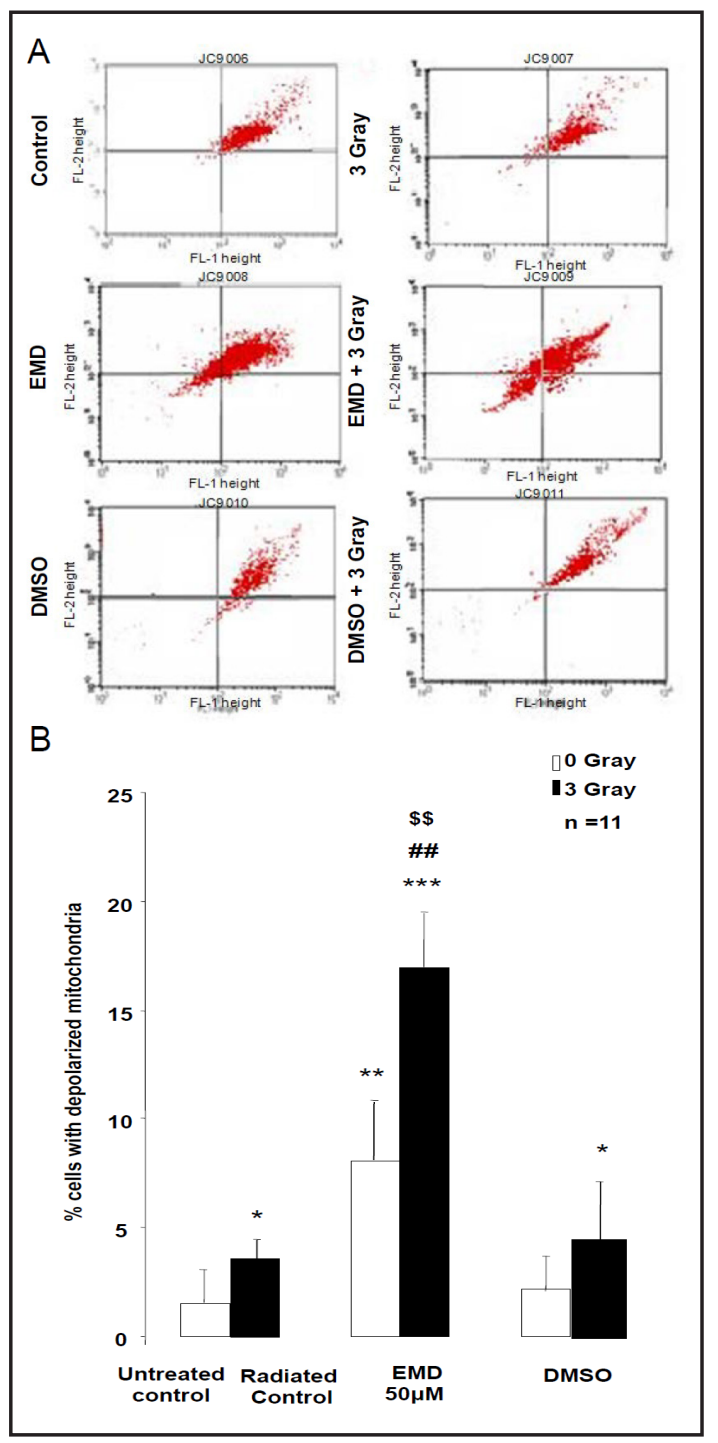

Fig. 2. Effect of radiation and/or EMD638683 on mitochondrial potential in CaCo-2 cells. A. Original dot plot of mitochondrial potential of colon carcinoma (Caco-2) cells without (left panel) and with (right panel) a 3.18 minutes exposure to radiation (3 Gray) $72 \mathrm{~h}$ prior to measurements without (-) and with (+) a $24 \mathrm{~h}$ exposure to $50 \mu \mathrm{M}$ EMD638683. B. Arithmetic means \pm SD $(n=11)$ of Caco- 2 cells with decreased mitochondrial potential following a 24 $\mathrm{h}$ exposure in the absence (control) or presence of $50 \mu \mathrm{M}$ EMD638683 (EMD) or $0.2 \mu \mathrm{l}$ solvent Dimethyl sulfoxide (DMSO) without (white bars) and with (black bars) a 3.18 minutes exposure to radiation (3 Gray). ${ }^{*}(\mathrm{p}<0.05),{ }^{* *}(\mathrm{p}<0.01),{ }^{* * *}(\mathrm{p}<0.001)$ indicates significant difference to respective value of untreated control; \#\# $(\mathrm{p}<0.01)$ indicates significant difference to respective value without radiation and $\$ \$$ $(\mathrm{p}<0.01)$ indicates significant difference to DMSO (t- test).

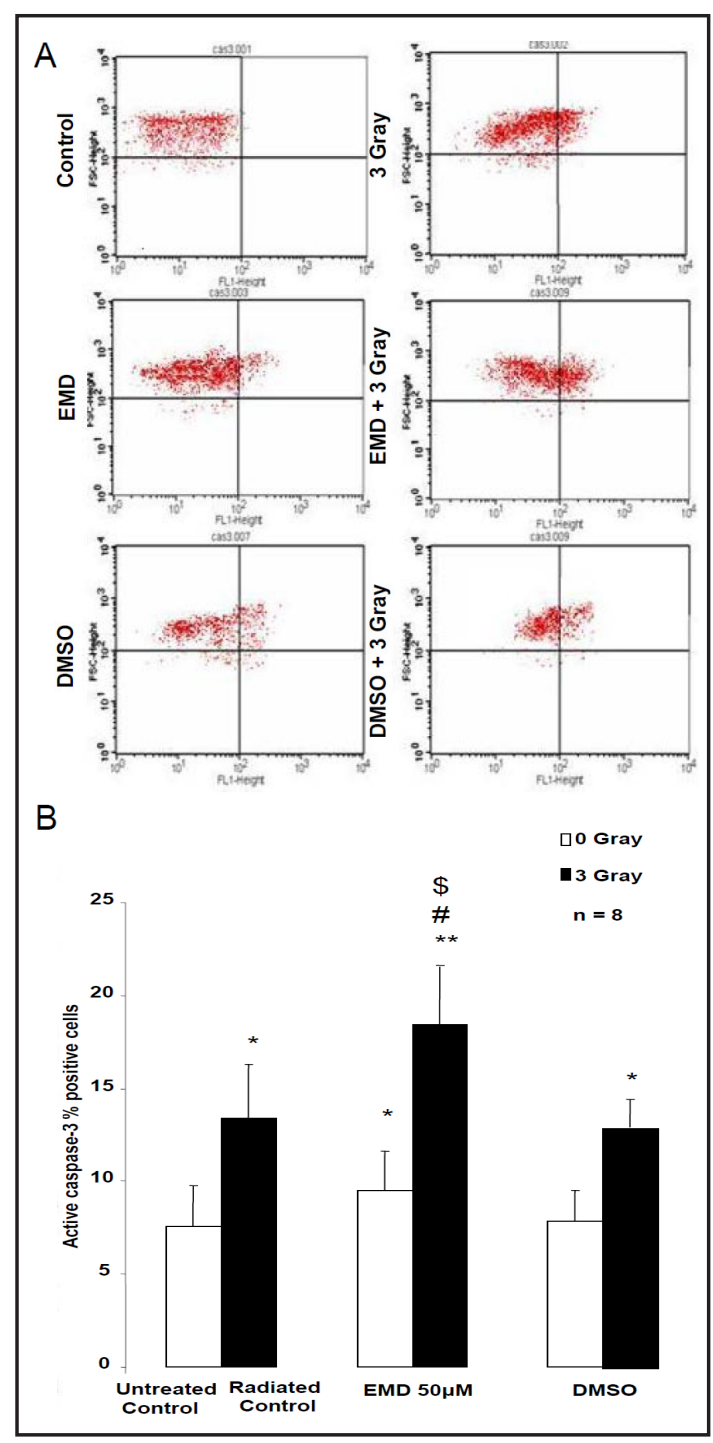

Fig. 3. Effect of radiation and/or EMD638683 on caspase-3 activity in CaCo-2 cells. A. Original dot plots of caspase- 3 activity in colon carcinoma (Caco2) cells without (left panel) and with (right panel) a 3.18 minutes exposure to radiation (3 Gray) $72 \mathrm{~h}$ prior to measurements without (-) and with (+) a 24 h exposure to $50 \mu \mathrm{M}$ EMD638683. B. Arithmetic means \pm SD $(n=8)$ of caspase- 3 activity in Caco- 2 cells following a $24 \mathrm{~h}$ exposure in the absence (control) or presence of $50 \mu \mathrm{M}$ EMD638683 (EMD) or $0.2 \mu \mathrm{l}$ solvent Dimethyl sulfoxide (DMSO) without (white bars) and with (black bars) an additional $3.18 \mathrm{mi}$ nutes exposure to radiation ( 3 Gray).* $(\mathrm{p}<0.05)$, ${ }^{* *}(p<0.01)$ indicates significant difference to respective value of untreated control and \# $(\mathrm{p}<0.05)$ indicates significant difference to respective value without radiation and $\$(\mathrm{p}<0.05)$ represents significant difference from DMSO ( $\mathrm{t}$-test). 


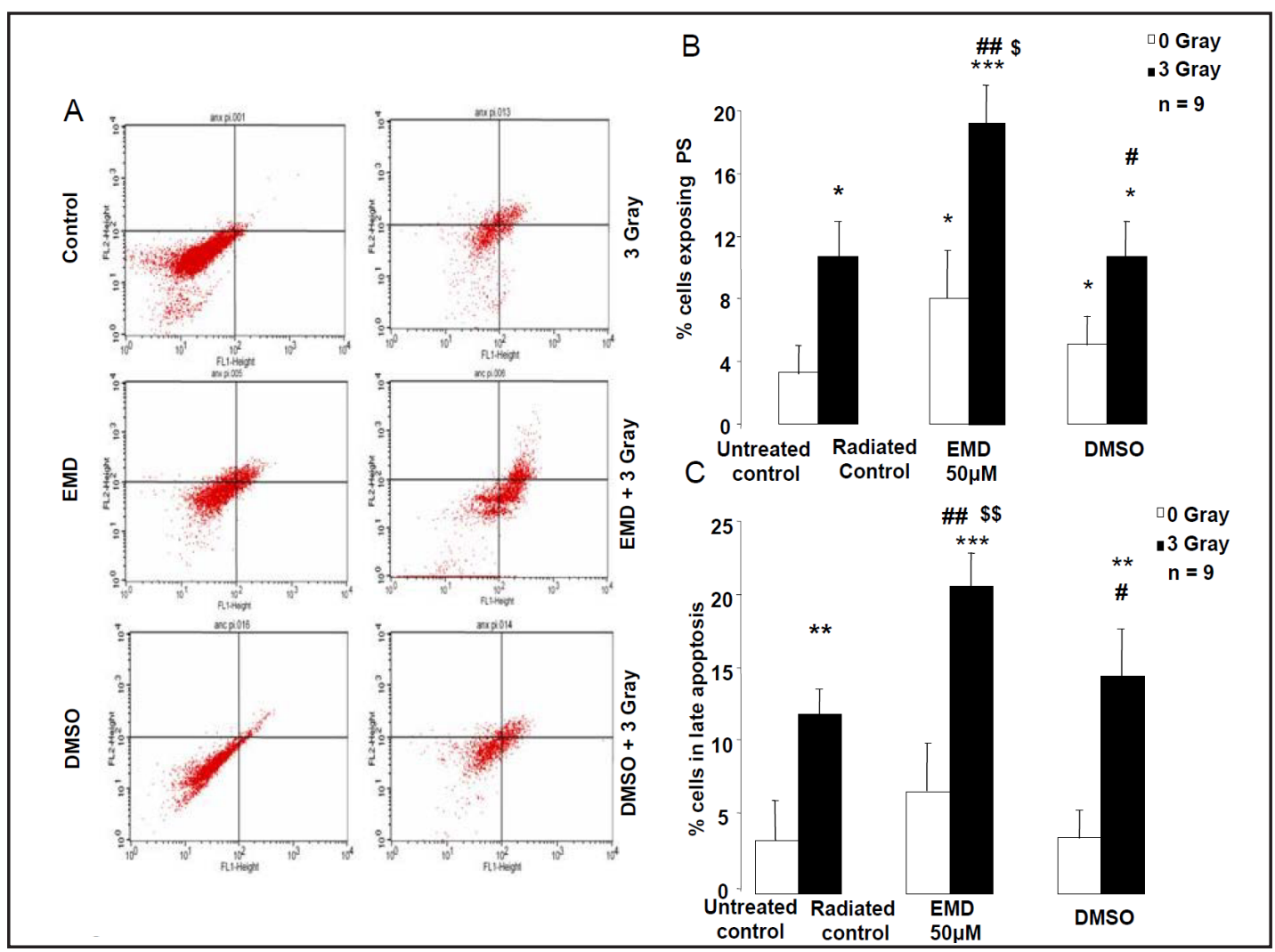

Fig. 4. Effect of radiation and/or EMD638683 on apoptosis of CaCo-2 cells. A. Original dot plots of apoptotic cells in colon carcinoma (Caco-2) cells without (left panel) and with (right panel) a 3.18 minutes exposure to radiation (3 Gray) $72 \mathrm{~h}$ prior to measurements without (-) and with (+) a $24 \mathrm{~h}$ exposure to $50 \mu \mathrm{M}$ EMD638683. The cells without externalized phosphatidylserine on the cell membrane and without degraded DNA appear on the lower left quadrant of the dot plot. B. Arithmetic means \pm SD ( $n=9)$ of the percentage Caco- 2 cells binding annexin-V following a $24 \mathrm{~h}$ exposure in the absence (control) or presence of $50 \mu \mathrm{M}$ EMD638683 (EMD) or $0.2 \mu$ l solvent Dimethyl sulfoxide (DMSO) without (white bars) and with (black bars) an additional 3.18 minutes exposure to radiation (3 Gray). Annexin V-FITC binds to externalized phosphatidylserine (PS). ${ }^{*}(\mathrm{p}<0.05),{ }^{* *}(\mathrm{p}<0.01)$ indicates significant difference to respective value of untreated control and \# $(\mathrm{p}<0.05)$, \#\#( $<<0.01)$ indicates significant difference from respective value without radiation and $\$(\mathrm{p}<0.05)$ indicates significant difference from DMSO (t-test). C. Arithmetic means \pm SD $(n=9)$ of the percentage Caco-2 cells undergoing late apoptosis following a $24 \mathrm{~h}$ exposure in the absence (control) or presence of 50 $\mu$ M EMD638683 (EMD) or $0.2 \mu$ l solvent Dimethyl sulfoxide (DMSO) without (white bars) and with (black bars) an additional 3.18 minutes exposure to radiation (3 Gray). Cells with degraded DNA allow propidium iodide (PI) to enter the cell. ${ }^{* *}(\mathrm{p}<0.05)$ and ${ }^{* * *}(\mathrm{p}<0.001)$ indicates significant difference to respective value of untreated control and \# $(\mathrm{p}<0.05)$ and \#\# $(\mathrm{p}<0.01)$ indicates significant difference to respective value without radiation and $\$$ represents significant difference from DMSO (t- test).

EMD638683-treated CaCo-2 cells was significantly higher than the percentage of apoptotic control cells. Thus, EMD638683 treatment significantly augmented the apoptosis following radiation.

In a second series of experiments the influence of EMD638683 on tumor growth was tested in vivo. To this end, wild type mice received either placebo food or food containing EMD638683 (4460 ppm in the chow, which resulted in a dose of approx. $600 \mathrm{mg} / \mathrm{kg} /$ day). The animals were exposed to chemical carcinogenesis by intra-peritoneal injection of the carcinogenic drug 1,2-dimethylhydrazine in $0.9 \%$ saline followed by 3 cycles of dextran sulfate sodium in the drinking water. As listed in Table 1, body weight was not significantly different between 
Table 1. Effect of chemical cancerogenesis on body and organ weight, as well as colon length. Body and organ weight as well as colon length of mice prior to (Start) and 12 weeks after treatment with the carcinogenic drug 1,2-dimethylhydrazine followed by dextran sulfate sodium (End) without (-EMD638683) and with (+EMD638683) treatment with EMD638683. Values are given with standard error of the mean. * indicates statistically significant difference between the respective value prior to and 12 weeks after the beginning of the 1,2-dimethylhydrazine + dextran sulfate sodium treatment; \# indicates statistically significant difference between -EMD638683 and +EMD638683

\begin{tabular}{|c|c|c|c|c|}
\hline & \multicolumn{2}{|c|}{-EMD638683 } & \multicolumn{2}{|c|}{ +EMD638683 } \\
\hline & Start $(n=11)$ & End $(n=8)$ & Start $(n=12)$ & End $(n=11)$ \\
\hline Body weight [g] & $19.58 \pm 1.21$ & $23.73 \pm 0.53^{*}$ & $18.52 \pm 1.04$ & $23.99 \pm 0.40^{*}$ \\
\hline Colon length $[\mathrm{cm}]$ & & $9.38 \pm 0.16$ & & $10.50 \pm 0.22^{\#}$ \\
\hline Colon weight [g] & & $0.96 \pm 0.04$ & & $0.80 \pm 0.03^{\#}$ \\
\hline Small intestine weight [g] & & $1.31 \pm 0.11$ & & $1.16 \pm 0.04$ \\
\hline Liver weight $[\mathrm{g}]$ & & $1.21 \pm 0.06$ & & $1.29 \pm 0.06$ \\
\hline Spleen weight [g] & & $0.15 \pm 0.01$ & & $0.15 \pm 0.01$ \\
\hline Stomach weight [g] & & $0.18 \pm 0.01$ & & $0.15 \pm 0.01^{\#}$ \\
\hline Lung weight $[\mathrm{g}]$ & & $0.23 \pm 0.03$ & & $0.20 \pm 0.01$ \\
\hline Heart weight [g] & & $0.14 \pm 0.01$ & & $0.14 \pm 0.01$ \\
\hline Kidney weight [g] & & $0.36 \pm 0.02$ & & $0.36 \pm 0.02$ \\
\hline
\end{tabular}

Fig. 5. Effect of chemical carcinogenesis on tumor incidence in absence and presence of SGK1 inhibitor EMD638683. Arithmetic means \pm SD $(n=8-11)$ of the number of colonic tumors in wild type mice 12 weeks after treatment with the carcinogenic drug 1,2-dimethylhydrazine followed by dextran sulfate sodium treatment without (white bar) and with (black bar) EMD638683 (600 mg/kg/day ) treatment . \# indicates significant difference from untreated mice (t-test).

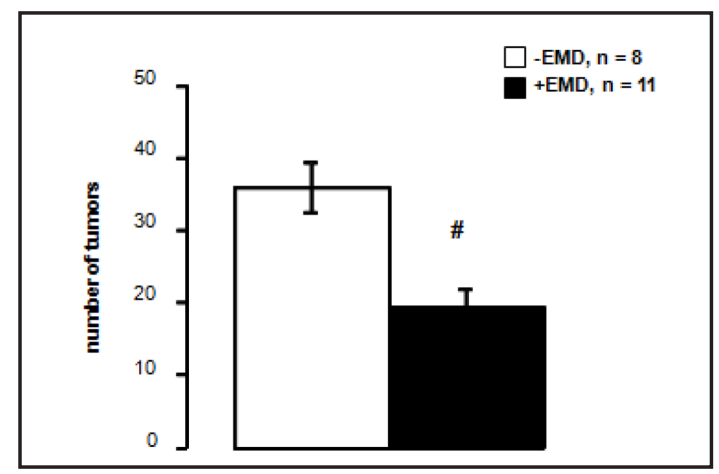

mice treated with EMD638683 and mice treated with placebo. Three animals did not survive in the group receiving placebo, and one animal did not survive in the EMD638683-treated group.

The colon was significantly longer and the colon weight significantly lower in EMD638683-treated mice than in placebo-treated mice (Table 1), a finding pointing to an influence of EMD638683 on tumor growth following chemical carcinogenesis. In addition, the stomach weight was significantly lower in the EMD treated group. Most importantly, the number of developing tumors following carcinogenic treatment was significantly blunted by EMD638683 treatment (Fig. 5).

\section{Discussion}

The present study reveals that the highly selective SGK inhibitor EMD638683 fosters the development of CaCo-2 cell apoptosis and sensitizes CaCo-2 cells to the apoptotic effect of radiation. Moreover, this is the first demonstration that pharmacological inhibition of SGK decreases tumor growth and/or survival in vivo.

We show that $50 \mu \mathrm{M}$ EMD638683 triggers and or enhances the effect of radiation on decrease in the cell volume (Fig. 1), depolarization of mitochondria (Fig. 2), activation of caspase-3 (Fig. 3) and induction of late apoptosis (Fig. 4). We further demonstrate that EMD638683 treatment decreases the development of tumors following chemical carcinogenesis in vivo (Fig. 5). 
The effect of EMD638683 on CaCo-2 cell apoptosis reached statistical significance following radiation. According to an earlier study [25], SGK1 transcription is stimulated by radiation of radiation-resistant tumor cells but not in radiation-sensitive tumor cells. Thus, the survival of tumor cells following radiation is a function of their ability to up-regulate SGK1 expression. SGK1 expression is further up-regulated by ultraviolet (UV) radiation [16]. SGK1 protects tumor cells not only against radiation but as well against chemotherapy. SGK1 silencing increases the toxicity of chemotherapeutic drugs [16]. Conversely, over-expression of SGK1 by glucocorticoids inhibits chemotherapy-induced apoptosis of breast cancer cells [26].

SGK1 modifies tumor growth via several mechanisms. SGK1 phosphorylates and thus inhibits the transcription factor FKRHL1 (FOXO3) [14, 17, 27-29], which in turn counteracts cell survival and fosters cell growth [30-32]. FOXO3a triggers apoptosis at least in part by stimulating the expression of the Bcl2-interacting mediator BIM (Bcl-2-interacting mediator of cell death) [33], a protein stimulating apoptosis and inhibiting cell proliferation [34, 35]. SGK1 further interacts with apoptosis by inhibiting FAS and FASL expression and thus FAS-dependent activation of caspase 8 [36]. SGK1 contributes to the phosphorylation and inhibition of glycogen synthase kinase (GSK) 3 [37], which in turn phosphorylates the oncogenic transcription factor $ß$-catenin [38]. Additional mechanisms presumably contributing to SGK1-dependent tumor cell survival include p53 [39-41], N-myc downstream

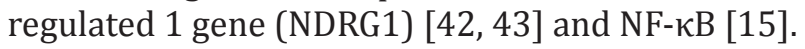

SGK1-dependent NF- $\kappa \mathrm{B}[15,44]$ stimulates the $\mathrm{Ca}^{2+}$ release activated $\mathrm{Ca}^{2+}$ channel $\left(\mathrm{I}_{\mathrm{CRAC}}\right)$ Orai1 $[45,46]$, a channel decisive in the regulation of cell proliferation $[47,48]$. SGK1 further up-regulates several $\mathrm{K}^{+}$channels, such as the voltage sensitive $\mathrm{K}^{+}$channel Kv1.3 [3, 4, 49, 50]. The $\mathrm{K}^{+}$channels maintain the cell membrane potential, which is in turn required for the function of $\mathrm{I}_{\text {CRAC }}[3,4]$.

SGK1 may further affect cell survival by stimulating cellular nutrient uptake. SGK1 up-regulates a wide variety of nutrient transporters [3] and may thus contribute to the excessive nutrient uptake by tumor cells. In view of the excessive glucose demand of tumor cells, SGK1-dependent stimulation of cellular glucose uptake may be particularly important for tumor cell survival [3]. SGK1 further up-regulates the activity of the $\mathrm{Na}^{+} / \mathrm{H}^{+}$exchanger [51]. The subsequent cytosolic alkalinization supports the excessive glycolytic flux in tumor cells [52].

SGK1 is up-regulated by ischemia $[53,54]$ and may participate in the stimulation of tumor vascularization [55].

The inhibition of tumor growth by EMD638683 is in full agreement with the former observations that lack of SGK1 decreases the number of spontaneous tumors in APC-deficient mice [11] and of colonic tumors following chemical carcinogenesis [12]. The present demonstration confirms that SGK1 is indeed an attractive pharmacological target in the treatment of tumors in vivo and that EMD638683 or a related substance could be effective in vivo. Notably, in the in vivo experiments, EMD638683 was applied without additional radiation, i.e. the substance was effective even without additional challenge of tumor cell survival.

Those observations are in seeming contrast to the reports of decreased SGK1 expression in prostate cancer [56], ovarian tumors [57], hepatocellular carcinoma [58] and adenomatous polyposis coli (APC) [3, 4, 10]. It has been speculated [12] that tumor cells with enhanced activation of the PI3K/ PKB/Akt cascade [59-61] are not dependent on SGK1 for survival. Loss-of-function mutations of the phosphatase and tensin homolog PTEN [62-64], for instance, result in excessive activation of PKB [60]. In view of the partially overlapping specificity of PKB/Akt and SGK1 [3], SGK1 may be dispensable in tumor cells with excessive $\mathrm{PKB} /$ Akt activity.

In conclusion, pharmacological inhibition of SGK1 with EMD638683 counteracts CaCo2 cell survival in vitro and colonic tumor growth in vivo. Thus, SGK1 may be an attractive pharmacological target in the treatment of malignancy. 
Towhid et al.: SGK1 Inhibition in Colon Carcinoma

\section{Acknowledgements}

The authors acknowledge the technical assistance of E. Faber and the meticulous preparation of the manuscript by Ali Soulanipour and Lejla Subasic. This study was supported by the Deutsche Forschungsgemeinschaft (GRK 1302 and SFB 773). and Open Access Publishing Fund of Tuebingen University.

\section{References}

1 Firestone GL, Giampaolo JR, O'Keeffe BA: Stimulus-dependent regulation of the serum and glucocorticoid inducible protein kinase (Sgk) transcription, subcellular localization and enzymatic activity. Cell Physiol Biochem 2003;13:1-12.

2 Waldegger S, Barth P, Raber G, Lang F: Cloning and characterization of a putative human serine/threonine protein kinase transcriptionally modified during anisotonic and isotonic alterations of cell volume. Proc Natl Acad Sci U S A 1997;94:4440-4445.

3 Lang F, Bohmer C, Palmada M, Seebohm G, Strutz-Seebohm N, Vallon V: (Patho)physiological significance of the serum- and glucocorticoid-inducible kinase isoforms. Physiol Rev 2006;86:1151-1178.

4 Lang F, Perrotti N, Stournaras C: Colorectal carcinoma cells--regulation of survival and growth by SGK1. Int J Biochem Cell Biol 2010;42:1571-1575.

5 Fagerli UM, Ullrich K, Stuhmer T, Holien T, Kochert K, Holt RU, Bruland O, Chatterjee M, Nogai H, Lenz G, Shaughnessy JD, Jr., Mathas S, Sundan A, Bargou RC, Dorken B, Borset M, Janz M: Serum/glucocorticoidregulated kinase 1 (SGK1) is a prominent target gene of the transcriptional response to cytokines in multiple myeloma and supports the growth of myeloma cells. Oncogene 2011;30:3198-3206.

6 Yoon JW, Gilbertson R, Iannaccone S, Iannaccone P, Walterhouse D: Defining a role for Sonic hedgehog pathway activation in desmoplastic medulloblastoma by identifying GLI1 target genes. Int J Cancer 2009;124:109-119.

7 Szmulewitz RZ, Chung E, Al Ahmadie H, Daniel S, Kocherginsky M, Razmaria A, Zagaja GP, Brendler CB, Stadler WM, Conzen SD: Serum/glucocorticoid-regulated kinase 1 expression in primary human prostate cancers. Prostate 2012;72:157-164.

8 Melhem A, Yamada SD, Fleming GF, Delgado B, Brickley DR, Wu W, Kocherginsky M, Conzen SD: Administration of glucocorticoids to ovarian cancer patients is associated with expression of the antiapoptotic genes SGK1 and MKP1/DUSP1 in ovarian tissues. Clin Cancer Res 2009;15:3196-3204.

-9 Abbruzzese C, Mattarocci S, Pizzuti L, Mileo AM, Visca P, Antoniani B, Alessandrini G, Facciolo F, Amato R, D'Antona L, Rinaldi M, Felsani A, Perrotti N, Paggi MG: Determination of SGK1 mRNA in non-small cell lung cancer samples underlines high expression in squamous cell carcinomas. J Exp Clin Cancer Res 2012;31:4.

10 Segditsas S, Sieber O, Deheragoda M, East P, Rowan A, Jeffery R, Nye E, Clark S, Spencer-Dene B, Stamp G, Poulsom R, Suraweera N, Silver A, Ilyas M, Tomlinson I: Putative direct and indirect Wnt targets identified through consistent gene expression changes in APC-mutant intestinal adenomas from humans and mice. Hum Mol Genet 2008;17:3864-3875.

11 Wang K, Gu S, Nasir O, Foller M, Ackermann TF, Klingel K, Kandolf R, Kuhl D, Stournaras C, Lang F: SGK1dependent intestinal tumor growth in APC-deficient mice. Cell Physiol Biochem 2010;25:271-278.

12 Nasir O, Wang K, Foller M, Gu S, Bhandaru M, Ackermann TF, Boini KM, Mack A, Klingel K, Amato R, Perrotti N, Kuhl D, Behrens J, Stournaras C, Lang F: Relative resistance of SGK1 knockout mice against chemical carcinogenesis. IUBMB Life 2009;61:768-776.

13 Brunet A, Park J, Tran H, Hu LS, Hemmings BA, Greenberg ME: Protein kinase SGK mediates survival signals by phosphorylating the forkhead transcription factor FKHRL1 (FOXO3a). Mol Cell Biol 2001;21:952-965.

14 Shelly C, Herrera R: Activation of SGK1 by HGF, Rac1 and integrin-mediated cell adhesion in MDCK cells: PI-3K-dependent and -independent pathways. J Cell Sci 2002;115:1985-1993.

15 Zhang L, Cui R, Cheng X, Du J: Antiapoptotic effect of serum and glucocorticoid-inducible protein kinase is mediated by novel mechanism activating I\{kappa\}B kinase. Cancer Res 2005;65:457-464.

16 Meng F, Yamagiwa Y, Taffetani S, Han J, Patel T: IL-6 activates serum and glucocorticoid kinase via p38alpha mitogen-activated protein kinase pathway. Am J Physiol Cell Physiol 2005;289:C971-C981.

17 Dehner M, Hadjihannas M, Weiske J, Huber 0, Behrens J: Wnt signaling inhibits forkhead box 03a-induced transcription and apoptosis through upregulation of serum- and glucocorticoid-inducible kinase 1. J Biol Chem 2008;283:19201-19210. 
18 Naishiro Y, Yamada T, Idogawa M, Honda K, Takada M, Kondo T, Imai K, Hirohashi S: Morphological and transcriptional responses of untransformed intestinal epithelial cells to an oncogenic beta-catenin protein. Oncogene 2005;24:3141-3153.

19 Sherk AB, Frigo DE, Schnackenberg CG, Bray JD, Laping NJ, Trizna W, Hammond M, Patterson JR, Thompson SK, Kazmin D, Norris JD, McDonnell DP: Development of a small-molecule serum- and glucocorticoidregulated kinase- 1 antagonist and its evaluation as a prostate cancer therapeutic. Cancer Res 2008;68:7475-7483.

20 Tangir J, Bonafe N, Gilmore-Hebert M, Henegariu O, Chambers SK: SGK1, a potential regulator of c-fms related breast cancer aggressiveness. Clin Exp Metastasis 2004;21:477-483.

21 Ackermann TF, Boini KM, Beier N, Scholz W, Fuchss T, Lang F: EMD638683, a novel SGK inhibitor with antihypertensive potency. Cell Physiol Biochem 2011;28:137-146.

22 Wang JG, Wang DF, Lv BJ, Si JM: A novel mouse model for colitis-associated colon carcinogenesis induced by 1,2-dimethylhydrazine and dextran sulfate sodium. World J Gastroenterol 2004;10:2958-2962.

23 Kohno H, Suzuki R, Sugie S, Tanaka T: Beta-Catenin mutations in a mouse model of inflammationrelated colon carcinogenesis induced by 1,2-dimethylhydrazine and dextran sodium sulfate. Cancer Sci 2005;96:69-76.

24 Santiago C, Pagan B, Isidro AA, Appleyard CB: Prolonged chronic inflammation progresses to dysplasia in a novel rat model of colitis-associated colon cancer. Cancer Res 2007;67:10766-10773.

25 Simon P, Schneck M, Hochstetter T, Koutsouki E, Mittelbronn M, Merseburger A, Weigert C, Niess A, Lang F: Differential regulation of serum- and glucocorticoid-inducible kinase 1 (SGK1) splice variants based on alternative initiation of transcription. Cell Physiol Biochem 2007;20:715-728.

-26 Wu W, Chaudhuri S, Brickley DR, Pang D, Karrison T, Conzen SD: Microarray analysis reveals glucocorticoidregulated survival genes that are associated with inhibition of apoptosis in breast epithelial cells. Cancer Res 2004;64:1757-1764.

27 Huang H, Tindall DJ: Dynamic FoxO transcription factors. J Cell Sci 2007;120:2479-2487.

-28 Liu D, Yang X, Songyang Z: Identification of CISK, a new member of the SGK kinase family that promotes IL-3-dependent survival. Curr Biol 2000;10:1233-1236.

29 Xu J, Liu D, Gill G, Songyang Z: Regulation of cytokine-independent survival kinase (CISK) by the Phox homology domain and phosphoinositides. J Cell Biol 2001;154:699-705.

30 Kandel ES, Hay N: The regulation and activities of the multifunctional serine/threonine kinase Akt/PKB. Exp Cell Res 1999;253:210-229.

-31 Mikosz CA, Brickley DR, Sharkey MS, Moran TW, Conzen SD: Glucocorticoid receptor-mediated protection from apoptosis is associated with induction of the serine/threonine survival kinase gene, sgk-1. J Biol Chem 2001;276:16649-16654.

-32 You H, Jang Y, You T, Okada H, Liepa J, Wakeham A, Zaugg K, Mak TW: p53-dependent inhibition of FKHRL1 in response to DNA damage through protein kinase SGK1. Proc Natl Acad Sci U S A 2004;101:14057-14062.

33 Ewings KE, Wiggins CM, Cook SJ: Bim and the pro-survival Bcl-2 proteins: opposites attract, ERK repels. Cell Cycle 2007;6:2236-2240.

-34 Dijkers PF, Medema RH, Pals C, Banerji L, Thomas NS, Lam EW, Burgering BM, Raaijmakers JA, Lammers JW, Koenderman L, Coffer PJ: Forkhead transcription factor FKHR-L1 modulates cytokine-dependent transcriptional regulation of p27(KIP1). Mol Cell Biol 2000;20:9138-9148.

-35 Dijkers PF, Medema RH, Lammers JW, Koenderman L, Coffer PJ: Expression of the pro-apoptotic Bcl-2 family member Bim is regulated by the forkhead transcription factor FKHR-L1. Curr Biol 2000;10:12011204.

-36 Amato R, Menniti M, Agosti V, Boito R, Costa N, Bond HM, Barbieri V, Tagliaferri P, Venuta S, Perrotti N: IL-2 signals through Sgk1 and inhibits proliferation and apoptosis in kidney cancer cells. J Mol Med 2007;85:707-721.

37 Sakoda H, Gotoh Y, Katagiri H, Kurokawa M, Ono H, Onishi Y, Anai M, Ogihara T, Fujishiro M, Fukushima Y, Abe M, Shojima N, Kikuchi M, Oka Y, Hirai H, Asano T: Differing roles of Akt and serum- and glucocorticoid-regulated kinase in glucose metabolism, DNA synthesis, and oncogenic activity. J Biol Chem 2003;278:25802-25807.

-38 Cohen P, Frame S: The renaissance of GSK3. Nat Rev Mol Cell Biol 2001;2:769-776.

-39 Amato R, D'Antona L, Porciatti G, Agosti V, Menniti M, Rinaldo C, Costa N, Bellacchio E, Mattarocci S, Fuiano G, Soddu S, Paggi MG, Lang F, Perrotti N: Sgk1 activates MDM2-dependent p53 degradation and affects cell proliferation, survival, and differentiation. J Mol Med (Berl) 2009;87:1221-1239. 
Towhid et al.: SGK1 Inhibition in Colon Carcinoma

40 Feng Z, Liu L, Zhang C, Zheng T, Wang J, Lin M, Zhao Y, Wang X, Levine AJ, Hu W: Chronic restraint stress attenuates p53 function and promotes tumorigenesis. Proc Natl Acad Sci U S A 2012;109:7013-7018.

41 Lyo D, Xu L, Foster DA: Phospholipase D stabilizes HDM2 through an mTORC2/SGK1 pathway. Biochem Biophys Res Commun 2010;396:562-565.

42 McCaig C, Potter L, Abramczyk 0, Murray JT: Phosphorylation of NDRG1 is temporally and spatially controlled during the cell cycle. Biochem Biophys Res Commun 2011;411:227-234.

43 Murakami Y, Hosoi F, Izumi H, Maruyama Y, Ureshino H, Watari K, Kohno K, Kuwano M, Ono M: Identification of sites subjected to serine/threonine phosphorylation by SGK1 affecting N-myc downstream-regulated gene 1 (NDRG1)/Cap43-dependent suppression of angiogenic CXC chemokine expression in human pancreatic cancer cells. Biochem Biophys Res Commun 2010;396:376-381.

-44 Vallon V, Wyatt AW, Klingel K, Huang DY, Hussain A, Berchtold S, Friedrich B, Grahammer F, Belaiba RS, Gorlach A, Wulff P, Daut J, Dalton ND, Ross J Jr, Flogel U, Schrader J, Osswald H, Kandolf R, Kuhl D, Lang F: SGK1-dependent cardiac CTGF formation and fibrosis following DOCA treatment. J Mol Med 2006;84:396404.

45 Lang F, Eylenstein A, Shumilina E: Regulation of Orai1/STIM1 by the kinases SGK1 and AMPK. Cell Calcium 2012;52:347-354.

-46 Eylenstein A, Schmidt S, Gu S, Yang W, Schmid E, Schmidt EM, Alesutan I, Szteyn K, Regel I, Shumilina E, Lang F: Transcription factor NF-kappaB regulates expression of pore-forming $\mathrm{Ca}^{2+}$ channel unit, Orai1, and its activator, STIM1, to control $\mathrm{Ca}^{2+}$ entry and affect cellular functions. J Biol Chem 2012;287:2719-2730.

47 Berridge MJ, Bootman MD, Lipp P: Calcium--a life and death signal. Nature 1998;395:645-648.

48 Berridge MJ, Bootman MD, Roderick HL: Calcium signalling: dynamics, homeostasis and remodelling. Nat Rev Mol Cell Biol 2003;4:517-529.

49 Gamper N, Fillon S, Huber SM, Feng Y, Kobayashi T, Cohen P, Lang F: IGF-1 up-regulates K ${ }^{+}$channels via PI3kinase, PDK1 and SGK1. Pflugers Arch 2002;443:625-634.

-50 Lang F, Shumilina E: Regulation of ion channels by the serum- and glucocorticoid-inducible kinase SGK1. FASEB J 2013; 27:3-12.

51 Rotte A, Pasham V, Eichenmuller M, Yang W, Bhandaru M, Lang F: Influence of dexamethasone on $\mathrm{Na}^{+} / \mathrm{H}^{+}$ exchanger activity in dendritic cells. Cell Physiol Biochem 2011;28:305-314.

52 Boiteux A, Hess B: Design of glycolysis. Philos Trans R Soc Lond B Biol Sci 1981;293:5-22.

53 Feng Y, Wang Y, Xiong J, Liu Z, Yard B, Lang F: Enhanced expression of serum and glucocorticoid-inducible kinase-1 in kidneys of L-NAME-treated rats. Kidney Blood Press Res 2006;29:94-99.

-54 Nishida Y, Nagata T, Takahashi Y, Sugahara-Kobayashi M, Murata A, Asai S: Alteration of serum/ glucocorticoid regulated kinase-1 (sgk-1) gene expression in rat hippocampus after transient global ischemia. Brain Res Mol Brain Res 2004;123:121-125.

55 Catela C, Kratsios P, Hede M, Lang F, Rosenthal N: Serum and glucocorticoid-inducible kinase 1 (SGK1) is necessary for vascular remodeling during angiogenesis. Dev Dyn 2010;239:2149-2160.

56 Rauhala HE, Porkka KP, Tolonen TT, Martikainen PM, Tammela TL, Visakorpi T: Dual-specificity phosphatase 1 and serum/glucocorticoid-regulated kinase are downregulated in prostate cancer. Int J Cancer 2005;117:738-745.

57 Chu S, Rushdi S, Zumpe ET, Mamers P, Healy DL, Jobling T, Burger HG, Fuller PJ: FSH-regulated gene expression profiles in ovarian tumours and normal ovaries. Mol Hum Reprod 2002;8:426-433.

58 Chung EJ, Sung YK, Farooq M, Kim Y, Im S, Tak WY, Hwang YJ, Kim YI, Han HS, Kim JC, Kim MK: Gene expression profile analysis in human hepatocellular carcinoma by cDNA microarray. Mol Cells 2002;14:382-387.

59 Cheng GZ, Park S, Shu S, He L, Kong W, Zhang W, Yuan Z, Wang LH, Cheng JQ: Advances of AKT pathway in human oncogenesis and as a target for anti-cancer drug discovery. Curr Cancer Drug Targets 2008;8:2-6.

60 Salmena L, Carracedo A, Pandolfi PP: Tenets of PTEN tumor suppression. Cell 2008;133:403-414.

61 Steelman LS, Abrams SL, Whelan J, Bertrand FE, Ludwig DE, Basecke J, Libra M, Stivala F, Milella M, Tafuri A, Lunghi P, Bonati A, Martelli AM, McCubrey JA: Contributions of the Raf/MEK/ERK, PI3K/PTEN/Akt/mTOR and Jak/STAT pathways to leukemia. Leukemia 2008;22:686-707.

62 Lian Z, Di Cristofano A: Class reunion: PTEN joins the nuclear crew. Oncogene 2005;24:7394-7400.

63 Oudit GY, Sun H, Kerfant BG, Crackower MA, Penninger JM, Backx PH: The role of phosphoinositide-3 kinase and PTEN in cardiovascular physiology and disease. J Mol Cell Cardiol 2004;37:449-471.

64 Sulis ML, Parsons R: PTEN: from pathology to biology. Trends Cell Biol 2003;13:478-483. 